\title{
Serbuk Daun Kelor Memulihkan Kondisi Fisik Gizi Buruk pada Tikus Model Kurang Energi Protein
}

\section{The Effect of Leaves Powder Moringa Oleifera in Physical Recovery of Protein Energy Malnutrition Rat Model}

\author{
Fifi Luthfiyah ${ }^{1}$, Eddy Widjajanto ${ }^{2}$ \\ ${ }^{1}$ Politeknik Kesehatan Mataram \\ ${ }^{2}$ Laboratorium Patologi Klinik Fakultas Kedokteran Universitas Brawijaya Malang
}

\begin{abstract}
ABSTRAK
Serbuk daun kelor (Moringa oleifera) lokal Nusa Tenggara Barat (NTB) merupakan alternatif tanaman kaya gizi yang berpotensi memperbaiki kondisi gizi buruk. Penelitian ini bertujuan mengetahui dampak serbuk daun kelor lokal NTB terhadap perbaikan gambaran fisik tikus model kurang energi proten (KEP) dengan desain post-test randomized control group in vivo pada dua puluh ekor tikus. Tikus dibagi dalam dua kelompok kontrol dengan diet normal dan rendah protein selama 56 hari untuk membuat tikus model KEP. Tiga kelompok perlakukan diberikan diet rendah protein selama 56 hari dan asupan serbuk daun kelor dengan dosis $180 \mathrm{mg}, 350 \mathrm{mg}$ dan $720 \mathrm{mg} /$ hari. Kondisi fisik tikus diukur dengan kriteria APGAR. Pemberian diet rendah protein pada tikus mampu mengembangkan model tikus dengan KEP yang menunjukkan tanda-tanda kurang gizi seperti berat badan yang menurun, kondisi fisik yang lemah dan penampilan fisik seperti bulu mudah rontok, kusam dan berkutu. Pemberian serbuk daun kelor lokal NTB dapat meningkatkan keadaan fisik kondisi KEP hingga mengarah ke keadaan fisik normal.
\end{abstract}

Kata Kunci: Kondisi fisik, kurang energi protein, Moringa oleifera

\section{ABSTRACT}

Protein Energy Malnutrition (PEM) problem at West Nusa Tenggara (NTB) remaining high. Powder of NTB kelor leaf (Moringa oleifera) is an alternative nutrient substance of rich plants. This research was aimed to prove the impact of local kelor leaf powder on the physical condition in mouse PEM model. An in vivo experimental laboratory study was performed using post-test randomized of control group design. Twenty mouses are divided in 2 control and 3 treatment groups. Two control groups represent negative control with normal diet and low protein diet in 56 days to develop mouse PEM model as positive control. Three groups were treated with low protein diet and administered with kelor leaf powder in three different dosages $180 \mathrm{mg}, 360 \mathrm{mg}$ and $720 \mathrm{mg}$ per day. Physical condition was measured using APGAR score. Mouse with low protein diet show a physical sign of PEM therefore can be used as PEM model. Administration of kelor leaf powder in mouse $P E M$ model show physical improvement equal to normal condition.

Keywords: Moringa oleifera, physical condition, protein energy malnutrition

Jurnal Kedokteran Brawijaya, Vol. 26, No. 3, Februari 2011; Korespondensi: Fifi Lutfiyah. Politeknik Kesehatan Mataram, Jl. Kesehatan V No.10Mataram Tel.(0370)622382Email:Iutfi_tyo@yahoo.co.id 


\section{PENDAHULUAN}

Masalah gizi yang masih menjadi problem di Indonesia adalah Kurang Energi Protein (KEP) (1). Penyebab KEP sangat kompleks. Masalah sosial ekonomi yang rendah menjadi penyebab utama asupan gizi yang kurang, sehingga disebut dengan malnutrisi primer (2). Kondisi KEP pada usia dini penting untuk ditangani karena mempengaruhi pertumbuhan otak dan kecerdasan intelektual. Kecerdasan intelektual yang diukur dengan tes kecerdasan secara positif berkorelasi signifikan dengan ukuran otak yang diukur dengan pencitraan resonansi magnetik (3). Penelitian Gulzar dan Rahman (1975), menunjukkan tikus yang mengalami kekurangan gizi protein yang parah setelah penyapihan memiliki bobot otak yang lebih rendah daripada kontrol (4).

Derajat klinis KEP dapat ditentukan menggunakan beberapa cara dan metode. Metode yang paling sering digunakan dan cukup mudah dilakukan adalah dengan melihat berat badan dan umur anak disesuaikan dengan grafik pada Kartu Menuju Sehat (5). Skrining gizi untuk mendeteksi kekurangan gizi kronis dilakukan dengan pemeriksaan fisik umum antara lain antropometri (berat badan/umur, berat badan/tinggi badan,panjang badan/tinggi badan), dada, perut, otot, jaringan lemak (5). Pemeriksaan fisik khusus (pemeriksaan mata, kulit, telinga hidung dan tenggorokan) dan pemeriksaan klinis (kadar gula darah, hemoglobin, albumin). Penampilan fisik kondisi KEP dapat dibedakan dengan kondisi normal. $\mathrm{Hal}$ ini penting untuk menegakkan diagnosa dan menentukan derajat keparahan kondisi KEP.

Mengingat potensi daun kelor lokal sebagai sumber asupan gizi, dilakukan penelitian untuk mengkaji efek serbuk daun kelor lokal NTB dalam memperbaiki kondisi fisik tikus model KEP. Penilaian dilakukan dengan melihat kondisi fisik sebagai cara yang mudah dan telah sering digunakan (5). Sebagai langkah awal penelitian ini juga mengkaji pengembangan tikus model KEP. Pengembangan model tikus dengan KEP setidaknya mempunyai dua fungsi strategis. Fungsi strategis yang pertama pengembangan tikus model KEP adalah untuk menjelaskan dasar biokima dan respon fisiologis terutama dalam metabolisme protein pada keadaan kekurangan gizi, atau undernutrisi primer. Disamping itu pengembangan tikus model juga ditujukan untuk menghasilkan replika dari dua sindrom klinis, Kwashiorkor dan Marasmus (6).

\section{METODE}

Hewan coba yang digunakan adalah tikus putih jantan Rattus novergicus strain Wistar berumur 5-6 minggu dengan berat 100-150 gr yang diperoleh dari Laboratorium Fisiologi Fakultas Kedokteran Universitas Brawijaya (FKUB). Jumlah tikus yang digunakan adalah 20 ekor yang diadaptasi selama 7 hari, dikelompokkan menjadi 2 kelompok kontrol dan 3 kelompok perlakukan selama 56 hari. Kelompok kontrol negatif (PO) diberikan diet normal dan kontrol positif diberikan diet rendah protein sebagai model tikus KEP. Ketiga kelompok perlakuan diberikan diet rendah protein dengan pemberian serbuk daun kelor pada tiga dosis berbeda yaitu $0,18 \mathrm{~g} /$ hari, $0,36 \mathrm{~g} /$ hari, dan $0,72 \mathrm{~g} /$ hari. Diet normal tikus terdiri atas comfeed PARS. Kandungan zat gizi per 100 gram bahan dari komposisi diet normal yang biasa digunakan di Laboratorium Farmakologi FKUB (Tabel 1).

Tabel 1. Komposisi gizi diet normal tikus per 100 gram

\begin{tabular}{lc}
\hline Zat Gizi & Comfeed PARS \\
\hline E (kkal) & 344 \\
P (gram) & 19 \\
L (gram) & 4 \\
KH (gram) & 58 \\
\hline
\end{tabular}

Dari penelitian sebelumnya (7), diketahui bahwa kebutuhan makan tikus per ekor setiap harinya adalah 2030 gram, sehingga kebutuhan energi tikus per hari (20 gram) adalah 68,6 kkal. Dari kebutuhan energi tikus per hari dapat diterjemahkan ke dalam bentuk makro nutrient sebagai berikut: protein $(19,07 \%)=19,07 \% \times 68,53 \mathrm{kkal}=$ $13,07 \mathrm{kkal}$, lemak $(7,79 \%)=7,79 \%$ X 68,53 kkal = 5,34 kkal, karbohidrat $(73,15 \%)=73,15 \% \times 68,53 \mathrm{kkal}=50,13 \mathrm{kkal}$. Diet rendah protein diberikan selama 56 hari (sampai berat badan tikus menunjukkan penurunan $20 \%$ dari berat badan awal) dengan komposisi gizi sebagai berikut: kadar protein 5,6\% dan kadar karbohidrat 67,8\% (8). Penampilan fisik tikus dinilai berdasarkan nilai Apgar yaitu (Activity (aktivitas), Pulse (nadi), Grimace (mimik), Appearance (tampilan kasat mata), dan Respiration (pernapasan). Nilai APGAR adalah parameter dalam menilai kenormalan tampilan fisik manusia (9). Data hasil pemeriksaan berat badan dan fisik dianalisis deskriptif.

Tabel 2. Perbandingan fisik tikus dengan diet normal dan kurang energi protein

\begin{tabular}{|c|c|c|}
\hline \multirow{2}{*}{ Parameter } & \multicolumn{2}{|c|}{ Perlakuan } \\
\hline & Tikus Normal & Tikus Kurang Energi Protein \\
\hline Usia & U : 5 mgg; BB : 90-110 gram & Tikus Kurang Energi Protein \\
\hline Berat Badan & $\mathrm{U}: 18 \mathrm{mgg} ; \mathrm{BB}: 150-250 \mathrm{gr}$ & \\
\hline Activity & Lincah, Spontan & Tidak ada gerakan sama sekali \\
\hline Pulse & 330-180/menit & Kurang dari 300/menit \\
\hline Gimic & $\begin{array}{l}\text { Bulu lembut, mengkilat tidak rontok. tidak ada kutu, } \\
\text { bulu disekitar ekor merata dan mulus } \\
\text { mata terbuka }\end{array}$ & $\begin{array}{l}\text { Bulu kasar, kusam, rontok, banyak kutu dan ada } \\
\text { luka disekitar ekor dan moncong } \\
\text { mata terpejam }\end{array}$ \\
\hline Appearance & $\begin{array}{l}\text { Warna kulit normal, Merata di seluruh tubuh, tampak } \\
\text { sehat }\end{array}$ & $\begin{array}{l}\text { Warna kulit pucat atau kebiruan diseluruh } \\
\text { tubuh,tremor, tampak sakit }\end{array}$ \\
\hline
\end{tabular}


Tabel 2. Perbandingan fisik tikus dengan diet normal dan kurang energi protein (lanjutan)

\begin{tabular}{lll}
\hline Respiration & $66-114 /$ menit & kurang dari 50/menit \\
Kulit dan Bulu & - Kulit putih kemerahan (segar) & - Kulit kusam putih kusam pucat \\
& - - julu bersih lebat & - Bulu rontok \\
& & Jaringan Lemak sangat sedikit \\
&
\end{tabular}

\section{HASIL}

Hasil pemberian diet rendah protein selama 56 hari menunjukkan perubahan fisik yang berbeda bila dibandingkan dengan tikus normal. Tikus menunjukkan tanda-tanda kurang gizi seperti bulu yang kusam dan mudah rontok, mata yang buram dan terlihat berkabut pada kornea, berat badan yang terus menurun dibandingkan dengan awal penelitian dan lain-lain. Tandatanda kurang gizi mulai tampak pada hari ke 30 setelah pemberian diet rendah protein. Pemberian diet rendah protein dapat menunjukkan tanda-tanda kurang gizi pada tikus, sehingga diet tersebut dapat digunakan sebagai acuan dalam merancang tikus model kurang energi protein (Tabel 2).

Pemberian serbuk daun kelor dalam tiga dosis mampu memberikan perbaikan kondisi fisik tikus yang dinilai dengan APGAR hingga mengarah ke kondisi normal. Pada dosis $0,18 \mathrm{~g} /$ hari sudah menunjukkan perbaikan aktifitas fisik namun belum memberikan perbaikan penampilan fisik. Pemberian serbuk daun kelor 0,36g/hari sudah lebih memberikan perbaikan tidak hanya pada aktifitas fisik tetapi juga nadi dan pernafasan serta jaringan lemak. Pada dosis $0,72 \mathrm{~g} /$ hari penampilan fisik tikus menunjukkan gambaran kondisi normal (Tabel 3).

Masing-masing tikus yang digunakan dalam penelitian memiliki usia rata-rata 5-6 minggu. Usia awal rata-rata semua tikus adalah 5 minggu 12 hari. Semua tikus dalam penelitian ini telah mendapat susuan dan saat diambil untuk penelitian tikus-tikus tersebut dalam masa penyapihan (lepas susuan). Bila dikonversikan ke manusia, usia awal tikus model setara dengan usia 2 tahun pada manusia yaitu umur balita disapih (10). Semua tikus diadaptasi selama satu minggu, diberi pakan berupa pellet dan minum (aquades). Tikus dikelompokkan menjadi 5 kelompok yang masing-masing mendapat makanan berbeda selama 56 hari ( 8 minggu). Selanjutnya diberikan serbuk daun kelor selama 30 hari (4 minggu), sehingga usia tikus pada akhir penelitian adalah 18 minggu 2 hari atau 4 bulan 17 hari.

Tabel 3. Gambaran fisik tikus model KEP dengan pemberian serbuk daun kelor pada tiga dosis

\begin{tabular}{|c|c|c|c|}
\hline \multirow{2}{*}{ Parameter } & \multicolumn{3}{|c|}{ Perlakuan Dosis Serbuk Daun Kelor } \\
\hline & $0,18 \mathrm{~g} /$ hari & $0,36 \mathrm{~g} /$ hari & $0,72 \mathrm{~g} /$ hari \\
\hline Usia dan Berat badan & U:18mgg BB130-140 gram & U:18mgg BB130-140 gram & U:18mgg BB130-140 gram \\
\hline Activity & Lincah, Spontan & Lincah, Spontan & Lincah, Spontan \\
\hline Pulse/Nadi & $300 / 350 /$ menit & 350/480/menit & 350/480/menit \\
\hline Grimace/Mimik & $\begin{array}{l}\text { Bulu kasar, kusam, berkutu, } \\
\text { luka dimoncong dan ekor, mata } \\
\text { terbuka kusam }\end{array}$ & $\begin{array}{l}\text { Bulu kasar, luka tidak ada, } \\
\text { mata terbuka }\end{array}$ & $\begin{array}{l}\text { Bulu bersih lebat, luka tidak } \\
\text { ada, mata terbuka }\end{array}$ \\
\hline Appearance/Rupa & $\begin{array}{l}\text { Warna kulit pucat, tremor, } \\
\text { tampak sakit }\end{array}$ & $\begin{array}{l}\text { Warna kulit putih kusam, merata } \\
\text { diseluruh tubuh tampak sehat }\end{array}$ & $\begin{array}{l}\text { Warna kulit normal, merata di } \\
\text { seluruh tubuh, tampak sehat }\end{array}$ \\
\hline Respiration & $60-75 /$ menit & $60-100 /$ menit & $60-110 /$ menit \\
\hline Kulit dan Bulu & $\begin{array}{l}\text { - Kulit kering kusam } \\
\text { - Bulu rontok } \\
\text { - Jaringan lemak Kurang }\end{array}$ & $\begin{array}{l}\text { - Kulit putih kusam } \\
\text { - Bulu rontok } \\
\text { - Jaringan lemak segar }\end{array}$ & $\begin{array}{l}\text { - Kulit putih kemerahan (segar) } \\
\text { - Bulu bersih lebat } \\
\text { - Jaringan lemak segar }\end{array}$ \\
\hline Gambar Fisik & & & \\
\hline
\end{tabular}




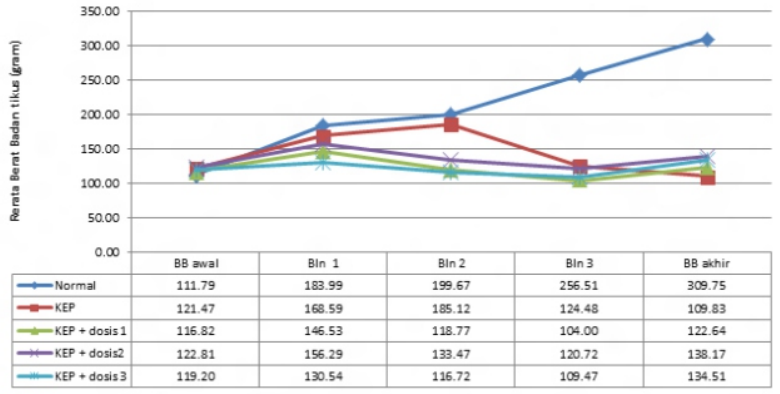

Gambar 1. Grafik perkembangan berat badan tikus masing-masing kelompok

Tikus model sebagai sampel penelitian memiliki berat badan yang beragam. Berat badan tikus dievaluasi sejak diambil dari tempat pemeliharaan, selama penelitian hingga akhir penelitian. Selama penelitian penimbangan berat badan dilakukan setiap minggu (Gambar 1). Pada penelitian ini tampak peningkatkan berat badan yang berbeda pada kelompok tikus normal dibandingkan kelompok lainnya. Pada kelompok KEP, tampak penurunan berat badan mulai bulan ke 2 setelah diberi diet kurang protein.

Pada saat awal penelitian seluruh tikus ditimbang untuk menilai status gizinya. Setelah diberikan perlakuan, keadaan berat badan menjadi menurun. Rata-rata penurunan berat badan tikus kelompok KEP adalah 121,4 $\pm 4,3$ (awal) dan 109,8 $\pm 13,2$ gram. Selain asupan yang kurang rata-rata kelompok tikus KEP tidak menghabiskan makanannya. Hal ini diketahui dari sisa makanan tikus yang dikonsumsi. Rata-rata sisa makanan tikus adalah 20 $50 \%$ dari berat makanan awal yang diberikan. Keadaan ini mungkin disebabkan desain dari pakan rendah protein yang tidak sebaik rasa, aroma dari pakan normal standar.

\section{DISKUSI}

Hasil penelitian menunjukkan penurunan berat badan tikus yang diberi perlakuan diet rendah protein. Hal ini sejalan dengan penelitian tentang KEP pada pasien di rumah sakit. Kurang energi protein adalah suatu keadaan tidak terpenuhinya energi, protein atau keduanya dari asupan makanan. Kurang energi protein pada pasien bisa terjadi karena proses penyakit yang dideritanya yang bisa mempengaruhi asupan makanan, meningkatkan kebutuhan, merubah metabolisme dan bisa terjadi malabsorpsi. Selain itu KEP juga disebabkan tidak adekuatnya asupan kalori makanan yang dikonsumsi oleh pasien. Umumnya kedua hal ini secara bersama-sama menyebabkan malnutrisi pada pasien (11). Makanan yang tidak termakan menyebabkan kurang terpenuhinya kebutuhan gizi, padahal metabolisme tubuh berjalan terus menerus. Metabolisme tanpa dibarengi dengan asupan nutrisi yang cukup dapat mengakibatkan pemecahan protein menjadi glukosa (glukoneogenesis) untuk pemenuhan kebutuhan akan glukosa (energi). Lebih jauh lagi akan terjadi defisit protein, sehingga pembentukan enzim, albumin dan immunoglobulin akan terganggu. Daya tahan tubuh akan menurun, sistem respon imun humoral (immunoglobulin) dan selularnya berespon lambat terhadap antigen yang masuk dapat meningkatkan resiko terkena penyakit lain. Pemecahan protein yang berlebihan juga berakibat penurunan cadangan protein yang jelas terlihat di otot (12).

Penilaian status malnutrisi fisik pada penelitian ini dilakukan dengan skor Apgar. Nilai Apgar pertama kali diperkenalkan oleh Viginia Apgar pada tahun 1952. Sejak itu sistem ini dipergunakan secara luas untuk menilai keadaan klinik bayi baru lahir. Pada mulanya skor Apgar digunakan sebagai cara yang mudah untuk menilai bayi baru lahir apakah memerlukan resusitasi dan mengevaluasi keberhasilan resusitasi (13). Cara ini dianggap yang paling ideal dan telah banyak digunakan. Patokan klinis yang dinilai adalah menghitung frekuensi jantung, melihat usaha bernafas, menilai tonus otot, menilai reflek rangsangan, memperhatikan warna kulit.

Penilaian kondisi fisik pada malnutri penting untuk dilakukan. Malnutrisi adalah hal yang dapat dihindari dan ditanggulangi, dengan pemberian dukungan nutrisi optimal dan tepat (14). Hendaknya dilakukan penilaian status gizi sejak awal dan status gizi ini terus dipantau. Hal ini ditujukan untuk mengidentifikasi individu-individu yang membutuhkan dukungan zat gizi segera, mencegah agar seseorang yang masih sehat tidak menderita permasalahan gizi, serta menghindari komplikasi lebih lanjut jika seseorang telah menderita masalah gizi. Tapi sayangnya penilaian status gizi ini jarang sekali dilakukan. Studi di Taiwan dan Canada menunjukkan hanya sebagian kecil staf rumah sakit yang dapat mengidentifikasi keadaan malnutrisi pada pasien yang dirawat $(14,15)$.

Pengamatan fisik menunjukkan terjadi penurunan denyut nadi pada tikus KEP ( $<300 /$ menit). Hal ini menunjukkan terjadi penurunan laju respirasi dan penurunan basal metabolic rate selama masa kronis intake nutrisi kurang. Keadaan ini berpengaruh terhadap aktivitas, mimic, pernafasan dan refleks. Tikus yang normal menunjukkan detak jantung yang normal, pernafasan yang baik, refleks normal, mimic dan bulu yang tumbuh lebat dan segar. Gambaran fisik tikus KEP mengarah pada kondisi balita dengan gizi buruk. Balita dengan marasmus memiliki ciriciri berat badannya kurang dari $60 \%$ berat anak normal seusianya, kulit terlihat kering, dingin dan mengendur, beberapa di antaranya memiliki rambut yang mudah rontok, tulang-tulang terlihat jelas menonjol, sering menderita diare atau konstipasi,dan tekanan darah cenderung rendah dibanding anak normal, dengan kadar hemoglobin yang juga lebih rendah. Balita dengan kwashiorkor memiliki ciri-ciri penderita nampak lemah dan ingin selalu terbaring, anemia, diare dengan feses cair yang banyak mengandung asam laktat karena berkurangnya produksi laktase dan enzim penting lainnya,kelainan kulit yang khas, dimulai dengan titik merah menyerupai petechia (perdarahan kecil yang timbul sebagai titik berwarna merah keunguan, pada kulit maupun selaput lendir), yang lambat laun kemudian menghitam. Setelah mengelupas, kulit terlihat kemerahan dengan batas menghitam. Kelainan ini biasanya dijumpai di kulit sekitar punggung, pantat. Saat rebahan, pembesaran hati dapat diraba dari luar tubuh, terasa licin dan kenyal. Keadaan marasmic kwashiorkor memiliki ciriciri gabungan keduanya (16).

Tikus model KEP dengan asupan serbuk daun kelor menunjukkan perbaikan fisik berdasarkan skor Apgar hingga mengarah ke kondisi normal. Pemulihan sempurna memerlukan waktu karena semakin lama periode laten (tikus terpapar diet kurang protein selama 56 hari), 
semakin lama pula perbaikan fisik tikus. Apabila rehabilitasi KEP lama tertangani, maka semakin besar insidens infeksi. Pengamatan juga menunjukkan adanya luka infeksi pada tikus. Tempat paling sering mengalami infeksi adalah traktus respiratorius (17).

Penelitian ini menggunakan kelor sebagai alternatif pemecahan KEP. Kelor adalah salah satu tanaman yang dapat tumbuh dengan mudah dan menyediakan semua asam amino esensial termasuk makro nutrien dan mikronutrien yang dibutuhkan manusia. Daun kelor yang segar memberikan asupan yang sangat baik dari Vitamin C, juga merupakan nutrisi penting, karena tubuh tidak memproduksi sendiri. Kandungan protein dalam Moringa cukup tinggi dan dapat dijadikan sumber protein nabati untuk memenuhi kebutuhan akan protein. Kandungan kalsium dalam kelor dapat dimanfaatkan dari daun kelor. Tanaman kelor mudah tumbuh, terutama di iklim panas.Hal ini menjadi salah satu keuntungan dari kelor yang mudah didapatkan di daerah tropis bahkan daerah yang kekeringan $(18,19)$.

\section{DAFTAR PUSTAKA}

1. Minarto. Rencana Aksi Pembinaan Gizi Masyarakat (RAPGM) Tahun 2010-2014. (Online) 2010. http://gizikia.depkes.go.id [diakses tanggal 20 Januari 2012].

2. Soekirman dan Jahari A. Penyimpangan Positif Masalah KEP di DKI Jakarta, Pedesaan Bogor Jawa Barat dan Lombok Timur NTB. Jakarta: LIPI-UNICEF; 2000.

3. Leiva PB, Inzunza BN, Perez $\mathrm{TH}$, et al. The Impact of Malnutrition on Brain Development, Intelligence and School Work Performance. Archivos Latinoamericanos de Nutricion. 2001; 51(1): 64-71.

4. Ahmad G and Rahman MA. Effect of Undernutrition and Protein Malnutrition on Brain Chemistry of Rats. The Journal of Nutrition. 1975; 105: 1090-1103.

5. Direktorat Jenderal Bina Kesehatan Masyarakat dan Direktorat Bina Gizi Masyarakat. Petunjuk Teknis Tatalaksana Anak Gizi Buruk. Buku II. Jakarta: Departemen Kesehatan Republik Indonesia; 2007.

6. Whitehead RG. Animal Models for the Study of Protein Energy Malnutrition. Proceeding of the Nutrition Society. 1980; 39: 227-231.

7. Hernowati ET, Therik JW, dan Hendra. Efek Nutritional Tepung Daun Kelor (Moringa oleifera) Varietas NTT terhadap Status Gizi Tikus Wistar KEP. [Tesis]. Universitas Brawijaya, Malang. 2009.

8. Laboratorium Studi Ilmu Hayati. Analisa Serbuk Karak. Malang: Universitas Brawijaya; 2009.

9. Corn YS. What is the Apgar Score? (Online) 16 Januari 2010. http://milissehat.web.id [diakses tanggal 6 Agustus 2010].
Penelitian ini membuktikan dengan pemberian serbuk daun kelor dosis 180 mg, 360 mg dan 720 mg per hari dapat meningkatkan keadaan fisik kondisi KEP mengarah ke keadaan fisik normal. Hasil yang hampir sama pada penelitian Ono, Rie (1998) yang menggunakan kedelai dalam mengatasi gizi kurang. Penelitian tersebut membuktikan bahwa tikus yang diberikan kedelai menunjukkan susunan kepadatan tulang yang berbeda dibandingkan dengan tikus yang tidak diberikan kedelai. Protein dan kalsium pada kedelai mampu meningkatkan kepadatan tulang dan komponen pembentuk tulang, dan mampu mencegah osteoporosis.

Dapat disimpulkan bahwa pemberian serbuk daun kelor pada tikus model KEP dapat memberikan perbaikan kondisi fisik tikus. Perlu dikaji lebih mendalam efek serbuk daun kelor lokal NTB terhadap pemeriksaan laboratorium dan biokimia darah. Penelitian dan kajian-kajian yang lebih mendalam pada tikus sebagai hewan coba perlu dilakukan, sehingga dapat diaplikasikan kepada manusia di masa yang akan datang.

10. Smith JB dan Mangkoewidjojo. Pemeliharaan, Pembiakan dan Penggunaan Hewan Coba di Derah Tropis. International Development Program of Australian Universities of Colleges. Jakarta: UI Press; 1988.

11. Fatimah, N. Malnutrisi di Rumah Sakit. Gizi Medik Indonesia. 2002; 1(1): 4-6.

12. Stroud M, Duncan $H$, and Nightingale J. Guidelines for Enteral Feeding in Adult Hospital Patient. An International Journal of Gastroenterology and Hepatology. 2003; 52(Suppl7): vii1-vii12.

13. Hasan R dan Alatas H. Buku Kuliah Ilmu Kesehatan Anak. Jilid 3. Jakarta: Balai Penerbit FK-UI; 2005.

14. Hu SP, Liu JF, and Shieh MJ. Nutrition Knowledge, Attitudes and Practices among Senior Medical Students in Taiwan. Journal of the American College of Nutrition. 1997; 16(5): 435-438.

15. Singh $\mathrm{H}$, Watt K, Veitch R, Cantor M, and Duerksen DR. Malnutrition is Prevalent in Hospitalized Medical Patients: Are House Staff Identifying the Malnourished Patient? Nutrition Journal. 2006; 22(4): 350-354.

16. Departemen Kesehatan RI. Pedoman Tata Laksana Balita Gizi Buruk. Jakarta: Dirjen Bina Kesehatan Masyarakat; 2004

17. Gibson and Rosalind S. Nutritional Assesment a Laboratory Manual. New York: Oxford University Press; 2005: p. 345-348.

18. Fuglie LJ. Combating Malnutrition with Moringa. Senegal: Bureau Regional Afrika; 2001.

19. Klause B. Moringa Oleifera-an Underutilized Tree with Amazing Versatility. University of Science and Technology, Kumasi-Ghana. 2004. 